\title{
Faecal contamination of water in the Lake Mellah and its catchment area, north-eastern Algeria
}

\author{
Wahida KHERIFI $^{1) \text { ABCDEF }}$, Lynda HECINI ${ }^{2) ~ D}$, Fedia BEKIRI ${ }^{3) ~ F}$, \\ Houria KHERICI-BOUSNOUBRA ${ }^{4)}$ E
}

1) orcid.org/0000-0001-7435-0765; Scientific and Technical Research Centre on Arid Regions, Campus of Mohamed Khider University, 7000 Biskra, Algeria; Badji-Mokhtar University, Laboratory Soil and Hydraulic, Annaba, Algeria; e-mail: wahidakherifi@yahoo.fr

2) orcid.org/0000-0002-4762-7885; Scientific and Technical Research Centre on Arid Regions, Biskra, Algeria; e-mail: lindahecini@yahoo.fr

3) orcid.org/0000-0001-8190-9168; Scientific and Technical Research Centre on Arid Regions, Biskra, Algeria; e-mail: sandi_elamel@yahoo.fr

4) Badji-Mokhtar University, Laboratory Soil and Hydraulic, Annaba, Algeria; e-mail: houria.kherici@univ-annaba.org

For citation: Kherifi W., Hecini L., Bekiri F., Kherici-Bousnoubra H. 2019. Faecal contamination of water in the Lake Mellah and its catchment area, north-eastern Algeria. Journal of Water and Land Development. No. 42 (VII-IX) p. 110-116. DOI: $10.2478 /$ jwld-2019-0051.

\begin{abstract}
Lake Mellah close to the Mediterranean Sea in north-eastern Algeria belongs to valuable ornithological sites with numerous, often migratory, birds. To achieve the research goal, seventeen (17) sampling points were sampled based on the urbanization of the watershed. Water samples were taken at different wadis levels (upstream and downstream of settlements), as well as at the wastewater treatment plant and in Lake Mellah based on four measurement campaigns conducted at one frequency seasonal (high water, low water) during the year (2011/2012). Biological parameters (coliform faecal bacteria, streptococci) were analysed in water of the lake and its affluents in the laboratory of the Department of Health and Population, El Taref by the most probable number (MPN) technique of the Mac Grady table taken from various points. Obtained results were processed by the use of Bourgeois ratio (coliform faecal bacteria: streptococci) to indicate the origin of faecal contamination of waters and to establish maps of the spatio-temporal evolution of this ratio by the software Surfer 9. This way we obtained information of contamination of human origin during the dry season coming from domestic waste waters. In winter the ratio showed animal prevalence of contamination coming primarily from Animal Park in El Kala.
\end{abstract}

Key words: affluents, biological parameters, Bourgeois ratio, faecal contamination, the Lake Mellah, waste waters

\section{INTRODUCTION}

Nowadays, problems with wastes constitute a danger increasingly important for the recipient environments [BOUSSAHA, LAIFA 2017]. Faecal pollution is closely linked to human and agricultural activities; this pollution comes in particular from the rejections of treated and untreated waste waters and excrements of animals, from the rejections of rain waters and other diffuse sources. Many studies relate to the combined effects of human activities and environmental factors microbiological contamination levels of the coastal zones with aquacultural interest [CHEDAD, ASSOBHEI 2005; 2007; CHIGBU et al. 2005; HUNTER et al. 1999]

The site of Lake Mellah has an international importance. It is used as a habitat for numerous animal and vegetable species, of which certain endemic or rare; from which it has an interest for the nature conservation [KHERIFI et al. 2012].

Around the Lake Mellah, agglomerations are settled in constant progression. The latter reaches currently more than 5,000 inhabitants. It has a strong tendency to extend 
its establishment and its activities. This is not without effects on quality of water which joins the Lake Mellah [KHERIFI et al. 2012].

The present study aims to evaluate the origin of faecal contamination in lake waters of the lake and its affluents by the use of Bourgeois ratio and to establish cardsto define the origin of the water pollution of the study area according to the report of Bourgeois.

\section{STUDY AREA}

The town of El Kala is located of the extreme Algerian littoral, sets in a national park which contains faunistic and floristic species. The creation of the park marks the accession of Algeria to the international action of wetland protection [SALAH-SALAH 2009].

The present study was carried out on the level of the National Park of El Kala (PNEK), through Lake Mellah and its catchment area considering that it constitutes an important natural heritage by the biological wealth of its habitats. The latter is part of the sea separated by a channel and arranged for fish breeding (Fig. 1).

Natural feature of Lake Mellah and its watershed. The Lake Mellah watershed represents a perimeter of $56.15 \mathrm{~km}$ covers a surface of $81.45 \mathrm{~km}^{2}$ [Head Office of the Forests 2015] by which the site receives the fresh water by precipitations of rain which fall directly on water stretch and by surface water from its pouring under-basin drained by Reguibetau Wadi in the North-West, Wadi Mellah in the South-West, Wadi El Aroug in the South, the sea in the North and finally by small waterways which are poured in the lake and which come from the eastern part of the basin represented by Wadi Boumalek in the North-East and rejection of wastewater treatment plant of the village of El Gantra El Hamra in the North-West (Fig. 2). The town of El Gantra El Hamra one of the villages are evacuated their discharges into a unit-type sanitation network in which the wastewater and rainwater and they undergo pretreatment by a sewage treatment plant operates on the basis of a lowactivated sludge process located in the west of the agglomeration near the national road No. 109, this station is undergo several phases of treatment: thunderstorm, fine mechanized screening, aeration basin, lamellar settling and sludge thickening.

Human and economic potential. The population settled around Lake Mellah is estimated according to the General Population and Housing Census (Fr. Recensement Général de la Population et de l'Habitat - RGPH) in 2008, at nearly 3,000 inhabitants [BABA AHMED 2008]. In 2015 it is estimated at more than 5,000 inhabitants [KHERIFI et al. 2016], but currently this number of population is not fixed in this region because it is a transitory population by their visitors.

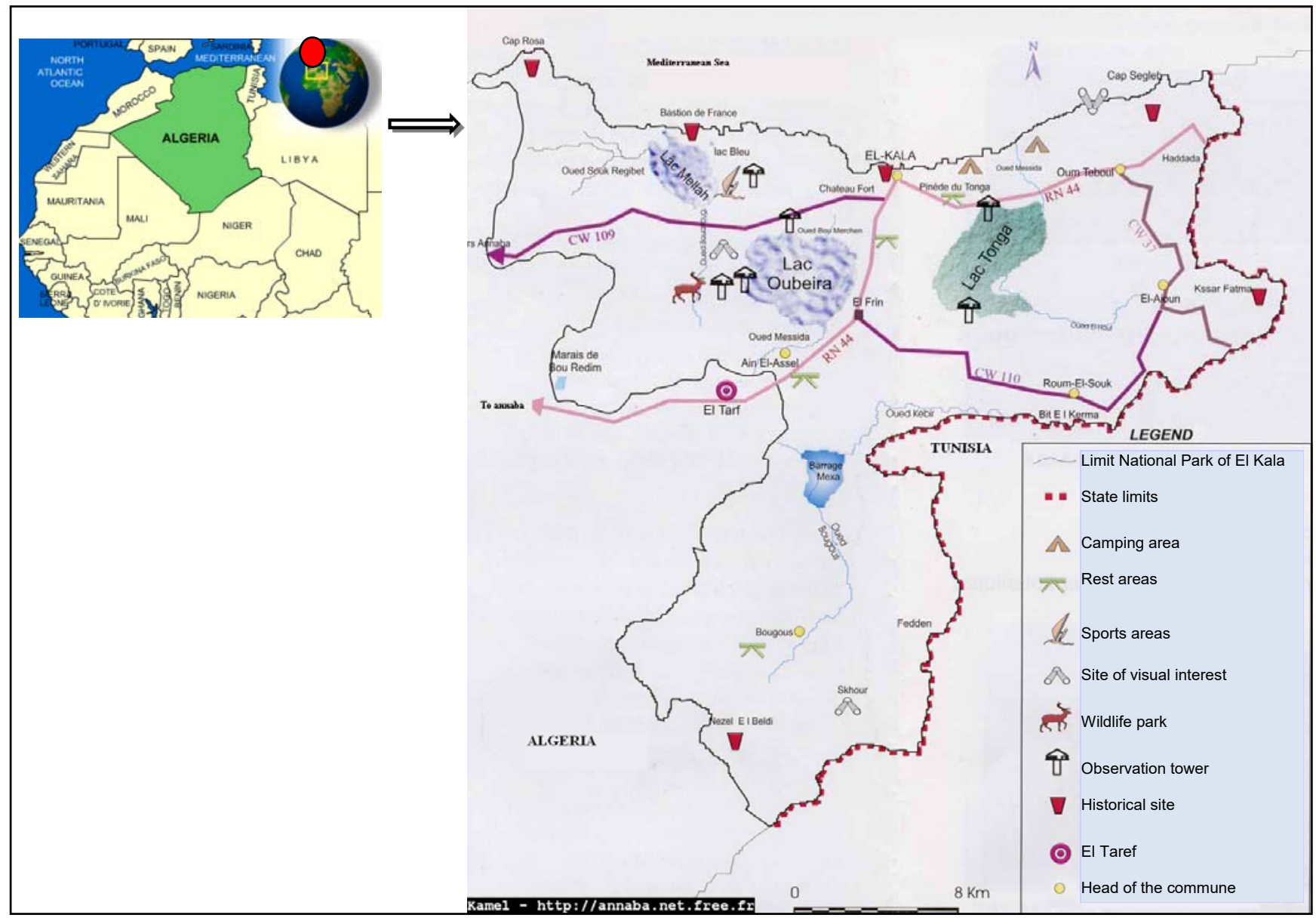

Fig. 1. Map of the National Park of El Kala (north-eastern Algeria); source: own elaboration 


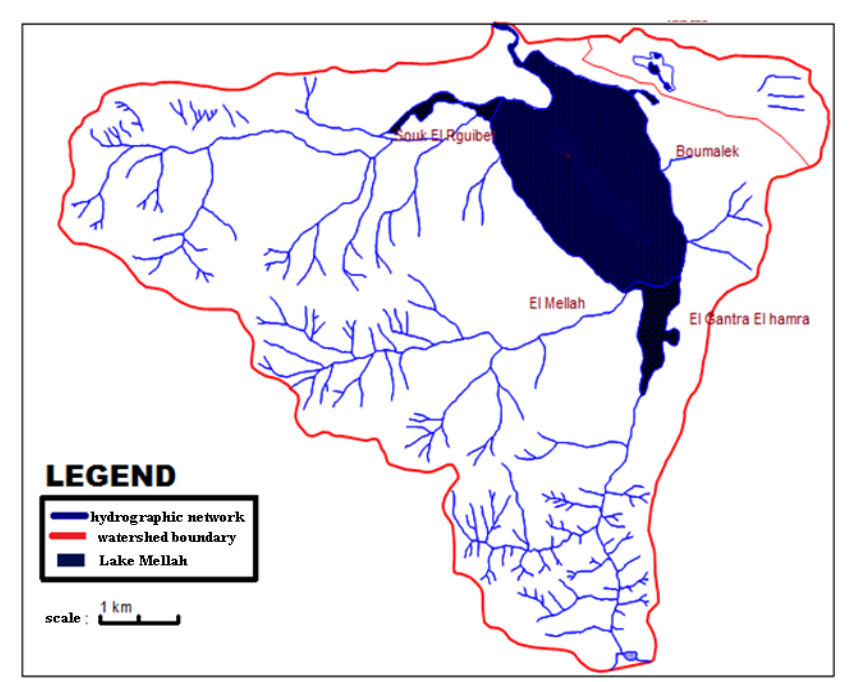

Fig. 2. Hydrographic map of network of the catchment area of the Lake Mellah; source: BABA AHMED[2008]

The local economic system of the entire study area is under developed; the available assets it dispose such as agriculture, livestock, fisheries and tourism are mobilized for informal activities. These activities are also increasing and influencing quality through the discharge of wastewater to the lake.

The douars of the Lake Mellah watershed consist of scattered dwellings and gardens in which the planimetry area is of 170 ha, i.e. $2 \%$ of the total. Most of the agricultural domain is arable land (Fig. 3), 130 ha are fallow left to the flock [BABA AHMED 2008].

The irrigated agriculture, which is carried out from the hydrographic network that feeds the lake's water stretch, boils down to a multitude of vegetable gardens, adjoining homes and peanut crops.

Livestock farming systems within the PNEK are of considerable importance to the rural economy. In the Mellah BV, the number of herds consists of 1,726 sheep, 500 goats and 3,132 cattle [BABA AHMED 2008].

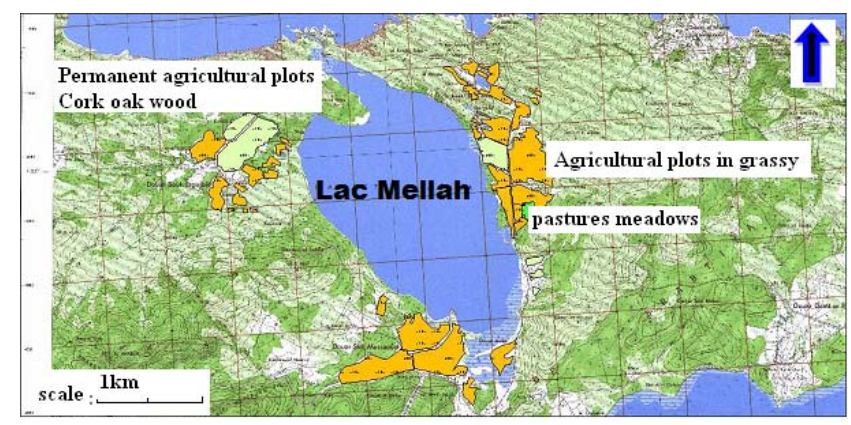

Fig. 3. Geographical location of agricultural parcels in the Lake Mellah basin;

source: Service de gestion agricole d'El Taref [2006]

\section{MATERIALS AND METHODS}

\section{MATERIALS}

Seventeen (17) intake points were sampled, chosen according to the urbanization of the catchment area. Our study will involve a biological hydro study of a Mediterranean lagoon on the basis of four series of measurements carried out at a seasonal frequency during the year (2011/2012) (spring, summer, autumn and winter). During these campaigns, two biological parameters (coliforms faecal, streptococci) were analysed at laboratory DSP (Fr. Directions de Santé et de la Population, El Taref) (Directorate of health and population, El Taref).

The glass vials $\left(500 \mathrm{~cm}^{3}\right)$ are used for sampling for bacteriological analysis, carefully washed, rinsed three times with distilled water and cured and sterilized $\left(120^{\circ} \mathrm{C}\right.$, $90 \mathrm{~min}$ ). After a hermetic sealing, the bottles (in situ) are put in a cooler at $4^{\circ} \mathrm{C}$, and get returned to the laboratory within less than $4 \mathrm{~h}$ for microbiological analysis.

The water samples were taken on the levels Wadis (upstream and downstream the urban areas), as well as on the level of the sewage treatment plant and in the Lake Mellah (Fig. 4). The details of the various sampling are taken by Global Positioning System (GPS) - Table 1.

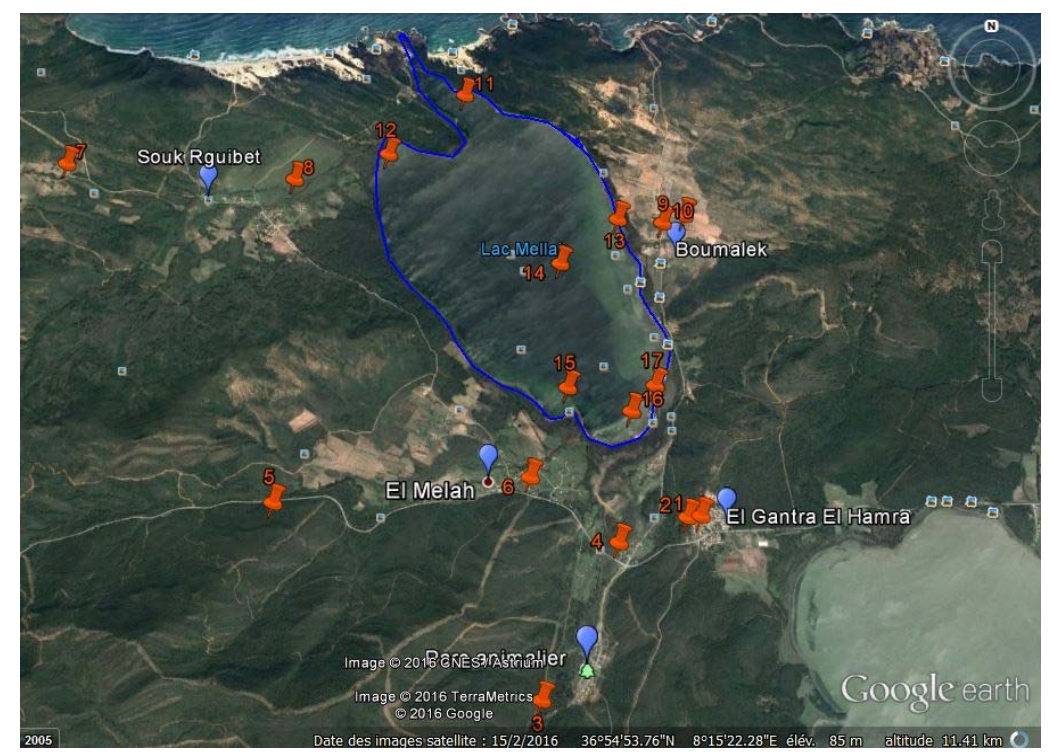

Fig. 4. Satellite sight of sites targeted for sampling; source: own elaboration 
Table 1. Inventory of the different sampling stations with name and address

\begin{tabular}{|l|l|c|c|c|}
\hline \multicolumn{2}{|c|}{ Name of the sampling station } & No. & $\begin{array}{c}\text { Coordinate } \\
\text { North }\end{array}$ & $\begin{array}{c}\text { Coordinate } \\
\text { East }\end{array}$ \\
\hline \multirow{4}{*}{$\begin{array}{l}\text { Wastewater } \\
\text { treatment plant }\end{array}$} & raw water & 1 & 36.52 .00 .0 & 8.20 .25 .6 \\
\cline { 2 - 5 } & clean water & 2 & 36.51 .51 .5 & 8.20 .38 .4 \\
\hline \multirow{5}{*}{ Wadis } & Wadi El Aroug upstream & 3 & 36.50 .51 .6 & 8.19 .30 .9 \\
\cline { 2 - 5 } & Wadi El Aroug downstream & 4 & 36.51 .45 .2 & 8.20 .06 .6 \\
\cline { 2 - 5 } & Wadi Mellah upstream & 5 & 36.52 .07 .0 & 8.17 .35 .1 \\
\cline { 2 - 5 } & Wadi Mellah downstream & 6 & 36.51 .21 .4 & 8.19 .38 .3 \\
\cline { 2 - 5 } & Wadi Souk Rguibet upstream & 7 & 36.54 .08 .3 & 8.15 .56 .8 \\
\cline { 2 - 5 } & Wadi Souk Rguibet downstream & 8 & 36.54 .01 .4 & 8.17 .42 .6 \\
\cline { 2 - 5 } & Wadi Boumalek upstream & 9 & 36.53 .40 .8 & 8.20 .41 .4 \\
\cline { 2 - 5 } & Wadi Boumalek downstream & 10 & 36.53 .40 .6 & 8.20 .35 .0 \\
\hline \multirow{5}{*}{ Lake } & channel of lake & 11 & 36.54 .39 .1 & 8.18 .22 .4 \\
\cline { 2 - 5 } & exit of Wadi Souk Rguibet & 12 & 36.54 .08 .4 & 8.18 .22 .4 \\
\cline { 2 - 5 } & exit of Wadi Boumalek & 13 & 36.53 .49 .7 & 8.20 .16 .2 \\
\cline { 2 - 5 } & center of the lake & 14 & 36.53 .27 .6 & 8.19 .45 .0 \\
\cline { 2 - 5 } & exit of Wadi Mellah & 15 & 36.52 .36 .0 & 8.19 .39 .8 \\
\cline { 2 - 5 } & exit of Wadi El Aroug & 16 & 36.52 .29 .0 & 8.20 .16 .1 \\
\cline { 2 - 5 } & $\begin{array}{l}\text { exit of the wastewater treatment } \\
\text { plant }\end{array}$ & 17 & 36.52 .35 .1 & 8.20 .25 .4 \\
\hline
\end{tabular}

Source: own elaboration.

Description of the tests on the research and enumeration of coliforms, faecal coliforms and faecal streptococci:

1. Research and enumeration of coliforms, faecal coliforms

The search and enumeration of coliforms, faecal coliform is done in two consecutive steps using the technique of the most probable number (MPN) of the table of Mac Grady:

- the presumption test: reserved for the research of coliforms in a medium BCPL (lactose bromide bromcresol broth, simple concentration) after an incubation at $37^{\circ} \mathrm{C}$ for $48 \mathrm{~h}$;

- the confirmationtest: reserved for the research of faecal coliforms on a more selective medium (LAV) at a temperature of $44^{\circ} \mathrm{C}$ for $24 \mathrm{~h}$.

\section{Detection and enumeration of faecal streptococci}

The research and enumeration of group (D) streptococci in water in a liquid medium using the most probable number (MPN) method of the Mac Grady table is also done in two consecutive steps:

- the presumptive stage: reserved for the search for streptococci, the enumeration is carried out in liquid medium on a single-concentration glucose broth with azide (Rothe); the incubator of the seeded tubes is carried out in the oven at $37^{\circ} \mathrm{C}$ for $24 \mathrm{~h}$; if the reaction is negative, the tubes are allowed to stay for $48 \mathrm{~h}$;

- the confirmatory stage: reserved for the actual confirmation of streptococci, carried out on the Litsky medium, the presence of streptococci is characterized by the appearance of a disorder with bacterial development with or without purple deposit.

\section{METHODS}

To see the nature of the bacterial contamination we used the Bourgeoisratio of (coliforms faecal to streptococci). The values of this ratio enables us to follow the origin of the contamination of water of the lake and its affluents to the level of the seventeen stations of the study, over the study period high waters (spring, summer) and low waters (autumn and winter), they were integrated under digital form by using the software Surfer 9, that makes it possible to carry out digital field/land models (MNT), resulting from the data collected on field via GPS [ALAMI SAMY 2011].

\section{RESULTS AND DISCUSSION}

\section{ORIGIN OF POLLUTION ACCORDING TO THE RATIO BOURGEOIS}

It is possible to know the origin of the faecal contamination by the use of the ratio (coliforms faecal to streptococci). This ratio is valid only when the contamination is recent because the faecal streptococci persist at greater length that the faecal coliforms in sea water [BOUCHRITI et al. 1992]. According to Bourgeois ratio when CF:SF is higher than 4 in more the share of the stations of study are important during the period of high water that low waters, the contamination is basically human origin if $\mathrm{CF}: \mathrm{SF}$ is less than 0.7 , the contamination is of animal origin and in this case, the cattle and particularly the sheep, seem to play a prevalent part in the contamination of water. The ratios $\mathrm{CF}$ :SF ranging between 0.7 and 4.0 will indicate that the bacteria come from the two sources at the same time, or the contamination is of mixed origin (Tab. 2).

Table 2. Origin of pollution according to the ratio of Bourgeois

\begin{tabular}{|c|c|c|c|c|}
\hline Station & $\begin{array}{l}\mathrm{CF}: \mathrm{SF} \\
\text { winter }\end{array}$ & $\begin{array}{c}\text { Probable source of } \\
\text { contamination }\end{array}$ & $\begin{array}{c}\mathrm{CF}: \mathrm{SF} \\
\text { summer }\end{array}$ & $\begin{array}{c}\text { Probable source of } \\
\text { contamination }\end{array}$ \\
\hline 1 & 2 & 3 & 4 & 5 \\
\hline 1 & 1.5 & $\begin{array}{l}0.7<\mathrm{CF}: \mathrm{SF}<4 \\
\text { mixed contamination } \\
\text { animal prevalence }\end{array}$ & 1.7 & $\begin{array}{l}0.7<\mathrm{CF}: \mathrm{SF}<4 \\
\text { mixed contamination } \\
\text { animal prevalence }\end{array}$ \\
\hline 2 & 0.5 & $\begin{array}{l}0.7>\mathrm{CF}: \mathrm{SF} \\
\text { animal contamination }\end{array}$ & 2.2 & $\begin{array}{l}0.7<\mathrm{CF}: \mathrm{SF}<4 \\
\text { mixed contamination }\end{array}$ \\
\hline 3 & 1.1 & $\begin{array}{l}0.7<\mathrm{CF}: \mathrm{SF}<4 \\
\text { mixed contamination }\end{array}$ & 3.8 & $\begin{array}{l}0.7<\mathrm{CF}: \mathrm{SF}<4 \\
\text { mixed contamination } \\
\text { human prevalence }\end{array}$ \\
\hline 4 & 1.0 & $\begin{array}{l}0.7<\mathrm{CF}: \mathrm{SF}<4 \\
\text { mixed contamination } \\
\text { animal prevalence }\end{array}$ & 5.2 & $\begin{array}{l}\mathrm{CF}: \mathrm{SF}>4 \\
\text { human contamination }\end{array}$ \\
\hline 5 & 2.6 & $\begin{array}{l}0.7<\mathrm{CF}: \mathrm{SF}<4 \\
\text { mixed contamination }\end{array}$ & 3.5 & $\begin{array}{l}0.7<\mathrm{CF}: \mathrm{SF}<4 \\
\text { mixed contamination } \\
\text { human prevalence }\end{array}$ \\
\hline 6 & 2.2 & $\begin{array}{l}0.7<\mathrm{CF}: \mathrm{SF}<4 \\
\text { mixed contamination }\end{array}$ & 6.0 & $\begin{array}{l}\mathrm{CF}: \mathrm{SF}>4 \\
\text { human contamination }\end{array}$ \\
\hline 7 & 2.7 & $\begin{array}{l}0.7<\mathrm{CF}: \mathrm{SF}<4 \\
\text { mixed contamination }\end{array}$ & 2.6 & $\begin{array}{l}0.7<\mathrm{CF}: \mathrm{SF}<4 \\
\text { mixed contamination }\end{array}$ \\
\hline 8 & 1.6 & $\begin{array}{l}0.7<\mathrm{CF}: \mathrm{SF}<4 \\
\text { mixed contamination } \\
\text { animal prevalence }\end{array}$ & 1.7 & $\begin{array}{l}0.7<\mathrm{CF}: \mathrm{SF}<4 \\
\text { mixed contamination } \\
\text { animal prevalence }\end{array}$ \\
\hline 9 & 1.3 & $\begin{array}{l}0.7<\mathrm{CF}: \mathrm{SF}<4 \\
\text { mixed contamination } \\
\text { animal prevalence }\end{array}$ & 2.0 & $\begin{array}{l}0.7<\mathrm{CF}: \mathrm{SF}<4 \\
\text { mixed contamination }\end{array}$ \\
\hline 10 & 1.3 & $\begin{array}{l}0.7<\mathrm{CF}: \mathrm{SF}<4 \\
\text { mixed contamination } \\
\text { animal prevalence }\end{array}$ & 2.9 & $\begin{array}{l}0.7<\mathrm{CF}: \mathrm{SF}<4 \\
\text { mixed contamination } \\
\text { human prevalence }\end{array}$ \\
\hline 11 & 0.5 & $\begin{array}{l}0.7>\mathrm{CF}: \mathrm{SF} \\
\text { animal contamination }\end{array}$ & 2.9 & $\begin{array}{l}0.7<\mathrm{CF}: \mathrm{SF}<4 \\
\text { mixed contamination } \\
\text { human prevalence }\end{array}$ \\
\hline 12 & 0.4 & $\begin{array}{l}0.7>\mathrm{CF}: \mathrm{SF} \\
\text { animal contamination }\end{array}$ & 0.8 & $\begin{array}{l}0.7<\mathrm{CF}: \mathrm{SF}<4 \\
\text { mixed contamination } \\
\text { human prevalence }\end{array}$ \\
\hline
\end{tabular}


continue Tab. 2

\begin{tabular}{|c|c|l|c|l|}
\hline 1 & 2 & \multicolumn{1}{|c|}{3} & 4 & \multicolumn{1}{|c|}{5} \\
\hline 13 & 0.9 & $\begin{array}{l}0.7<\mathrm{CF}: \mathrm{SF}<4 \\
\text { mixed contamination } \\
\text { animal prevalence }\end{array}$ & 1.5 & $\begin{array}{l}0.7<\mathrm{CF}: \mathrm{SF}<4 \\
\text { mixed contamination } \\
\text { human prevalence }\end{array}$ \\
\hline 14 & 0.0 & $\begin{array}{l}0.7>\mathrm{CF}: \mathrm{SF} \\
\text { animal contamination }\end{array}$ & 0.6 & $\begin{array}{l}0.7>\mathrm{CF}: \mathrm{SF} \\
\text { animal contamination }\end{array}$ \\
\hline 15 & 1.7 & $\begin{array}{l}0.7<\mathrm{CF}: \mathrm{SF}<4 \\
\text { mixed contamination } \\
\text { animal prevalence }\end{array}$ & 1.1 & $\begin{array}{l}0.7<\mathrm{CF}: \mathrm{SF}<4 \\
\text { mixed contamination } \\
\text { human prevalence }\end{array}$ \\
\hline 16 & 0.0 & $\begin{array}{l}0.7>\mathrm{CF}: \mathrm{SF} \\
\text { animal contamination }\end{array}$ & 5.0 & $\begin{array}{l}\mathrm{CF}: \mathrm{SF}>4 \\
\text { human contamination }\end{array}$ \\
\hline 17 & 0.6 & $\begin{array}{l}0.7>\mathrm{CF}: \mathrm{SF} \\
\text { animal contamination }\end{array}$ & 0.5 & $\begin{array}{l}0.7>\mathrm{CF}: \mathrm{SF} \\
\text { animal contamination }\end{array}$ \\
\hline
\end{tabular}

Explanation: $\mathrm{CF}: \mathrm{SF}=$ ratio of coliforms faecal to streptococci. Source: own study.

The presented results in the previous table show that the values of the Bourgeois ratio in most of the study stations are important during the summer period that wintry time, this importance is strongly related to the effect of the high temperature and the scarcity of precipitations which cause the increase of concentration of pathogens in the water which favours the human contamination (CF:SF) $>4$ ). These results are confirmed by other authors [MEHANNED 2014]. Ratio CF:SF varies in time [BERTRAND-KRAJEWSKI 2006]. Though the presence of faecal coliforms usually testifies a contamination of faecal origin. Several observed faecal coliforms is not of faecal origin, coming rather from water enriched in organic matters [BARTHE et al. 1998; OMS 2000].

\section{CARTOGRAPHY OF THE ORIGIN OF MICROBIAL POLLUTION}

The values of the origin of microbial pollution vary in time; one notes sometimes significant variations between the two periods (high and low waters). For better illustrating the data, cards of the spatio-temporal evolution of the ratio of Bourgeois were drawn up.

- Chart of the origin of the water pollution of the zone of study during the time of high waters

The representation of the bacterial contamination through the ratio of Bourgeois enabled us to draw up cards.

In Figure 5, we note a beach of contamination is of origin mixed important animal prevalence being spread out North in South-East of the zone of study whose ratio is higher than 1.5. The contamination is mixed coming at the same time from a domestic pollution and an agricultural pollution related to the effluents of breeding and progressively the prevalence decreases in the lake which undergoes a pure animal contamination coming from the places where the breeding is important, by consequence pollution comes from the manures and the cuff. Broadly the ratio of Bourgeois decreases as the distance of the upstream towards the point of the rejection of water of the lake. What clearly shows a reduction in this ratio according to the contribution of rainwater in water of the Wadi's and the wastewater treatment plant (dilution) on the one hand, and in addition it depends on salinity on the level on the Lake Mellah on the other hand.

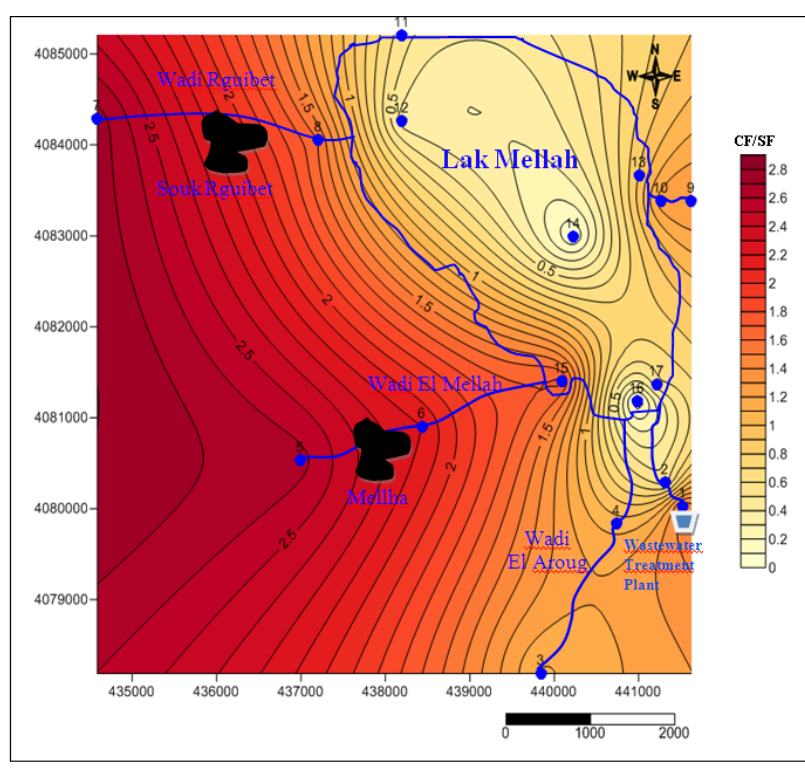

Fig. 5. Map of water pollution origin of the study zone according to Bourgeois ratio - the period of high waters; source: own study

\section{- Chart of the origin of the water pollution of the study zone during the time of low waters}

The chart for the summer period of the ratio of the origin of pollution (Fig. 6) shows the nature change of contamination which results in an increase in value of this ratio from the entry to the exit of sewage treatment plant and from the upstream to the downstream of the Wadis, while those higher than 4 will indicate a human origin to exit of sewage treatment plant and the Wadis. This confirms on the one hand that the high temperature does not seem to affect the decontamination of water [OLIVIER 2005] and that it can be dependent on the contributions of faecal matter waste water urban on the other hand which feeds the Wadis downstream the agglomeration urban area. This nature of contamination also well appeared in the outlet system of the principal Wadis which feed the Lake Mellah, which presents: Wadi El Mellah and Wadi Aroug.

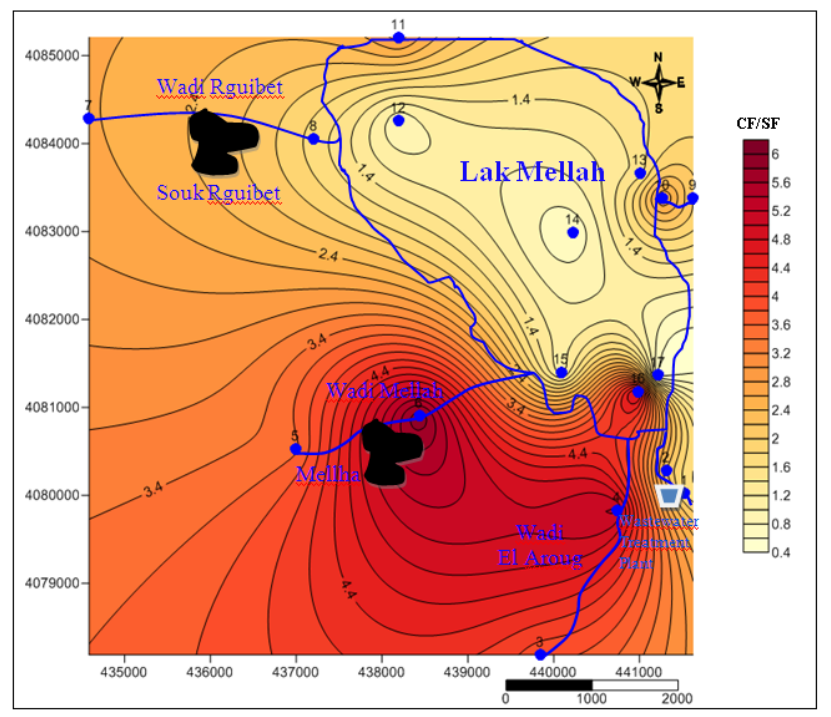

Fig. 6. Map of water pollution origin of the study zone according to Bourgeois ratio - the period of low waters; source: own study 
The diminution in the ratio on the level of the lake is due to rising salinity during summer period. The lake undergoes an animal contamination except in the station (16) carries a human contamination; this is explained by the fact of an anthropic action during summer because of an intensification of tourist activities downstream the lagoon (animalist park). These results resemble the results of the Oualidia lagoon in Morocco which is influenced by a certain number of factors with a predominance of marine effects, absence of a permanent waterway which directly feeds the lagoon [HENNANi MOUNA 2014].

On the cartography plan, our results constitute the first references for the development of a base of the geographical data concerning the probable source of the origin of pollution of the Lake Mellah and its affluents. Pluviometry and salinity are considered as paramount factors of positive purposes of the spatio-temporal distribution of the faecal bacteria on the Lake Mellah and of its affluents [KHERIFI et al. 2012; 2016]. Thus in rainy period, the streaming of the grounds soils rich in organic manure explains the condensation of faecal contaminants of animal origin on the level of the Lake Mellah.

Summer is marked by a faecal pollution of mixed or purely human origin concentrated downstream the lake. That is explained by the intensification of the touristic activities in the area during the period of summer. Other environmental parameters such as temperature, salinity and $\mathrm{pH}$ of water, also intervene in the spatio-temporal distribution. These results are confirmed by other authors [KHERIFI et al. 2016].

\section{CONCLUSIONS}

This study made it possible to enrich knowledge on the contamination problematic of lagoon water by faecal bacteria. The origin of this pollution is calculated from Bourgeois ratio confirms a pollution of human origin $(\mathrm{CF}: \mathrm{SF}>4)$ in the period of low waters coming from local waste water and of animal origin $(0.7>\mathrm{CF}: \mathrm{SF})$ in the period of high waters coming essentially from animal park of El Kala.

The current situation leads us to propose solutions for water protection upstream even to remedy and identify the problem of increasing degradation of water quality of Lake Mellah by assuming protection proposals by the implementation of a main sewage collector.

\section{REFERENCES}

Alami Samy 2011. Tutoriel d'utilisation de Surfer 9 [Tutorial of use To surf 9]. Stagiaire Caribsat. Action 6]. Martinique. Centre IRD pp. 23.

BABA AHMED R. 2008. Identification of the sources of domestic effluents and ways of contamination of a wetland: Case of the Lake Mellah. MSc Thesis. University Annaba pp. 189.

Barthe C., Perron J., Perron J.M.R. 1998. Guide of interpretation of the microbiological parameters of interest in the field of drinking water. (Preliminary version). Department of the Environment Working Paper of Quebec pp. 155.
BERTRAND-KRAJEWSKI J.-L. 2006. Les polluants des rejets urbains de temps de pluie: natures, concentrations, flux, caractéristiques physico-chimiques, solides en suspension, et répartition temporelle durant les événements pluvieux [Pollutants of the urban rejections of time of rain: physicochemical natures, concentrations, flows, characteristics, solids in suspension, and temporal distribution during the rainy events]. Course of Urban Hydrology. Partie No. 7. Lyon. URGC - Urban Hydrology pp. 53.

Bouchriti N., El MarraKchi A., FAHIM A. 1992. The microbiological contamination of an oyster growing area in Morocco, the Oualidia lagoon. Hydroécologie Appliquee. Vol. 4. Iss. 12 p. $189-202$.

BoussaHA S., LAIFA A. 2017. Wadi Bounamoussa's waters quality in the north-east of Algeria: Statistical treatment of some physical and chemical parameters. Journal of Water and Land Development. No. 34 p. 77-83. DOI 10.1515/jwld-20170040.

CHedAD K., Assobhei O. 2005. Study of the bacterial populations of the lagoon of Oualidia (Morocco). Reviews in Biology and Biotechnology. Vol. 4. Iss. 2 p. 33-42.

CHEDAD K., AssobHei O. 2007. Study of the survival of the bacteria of fecal contamination (coliformes fecal) in water of the oyster zone of the lagoon of Oualidia (Morocco). Bulletin of L Institute Scientific, Reduction. Sect. Life Sciences. No. 29 p. 71-79.

Chigbu P., Gordon S., Strange T.R. 2005. Fecal coliform bacteria disappearance rates in a north-central Gulf of Mexico estuary. Estuarine, Coastal and Shelf Science.Vol. 65. Iss. 1-2 p. $309-318$

Head Office of the Forests. 2015. National parks of Algeria; first meeting of the steering committee of the "Network of the parks - INTERREG IIIC South" Naples-Italy, from January 29th to February 1st, 2005.

HENNANi M. 2014. Bacteriological quality of water of the Oualidia lagoon "cartography and modeling of fecal pollution - Morocco. PhD Thesis. El Jadida, Morocco. University Chouaib Doukkali pp. 174.

Hunter C., Perkins J., Tranter J., Gunn J. 1999. Agricultural land-use effects on the indicator bacterial quality of an upland stream in the Derbyshire Peak District in the UK. Water Research. Vol. 33 p. 3577-3586.

KHeRifi W., Kherici-Bousnoubra H. 2012. Evolution saisonniere de la qualite microbiologique des eaux du lac Mellah (Nord-Est algerien) [Seasonal evolution of the microbiological quality of water of the Lake Mellah (north-eastern Algerian)]. Larhyss Journal. No. 11 p. 109-118.

KHERIFI W., KHERICI-Bousnoubra H. 2016. Study of the influence of the physicochemical parameters on microbial abundance in various ambient conditions. Water Resources. No. 43. Iss. 3 p. $546-558$.

MEHANNED S. 2014. Estimation of the bacterial pollution load of two tributaries (Mikke and Mellah) and its impact on the microbiological quality of the waters of the Sidi Chahed dam (Morocco). IOSR Journal of Engineering (IOSRJEN), ISSN (e): 2250-3021, ISSN (p): 2278-8719

OLIVER J.D. 2005. The viable but nonculturable state in bacteria. Journal of Microbiology. Vol. 43 p. 93-100.

OMS 2000. Directives of quality for the drink water. Vol. 2. Criteria of hygiene and documentation to the support. $2^{\text {nd }}$ ed. Geneva. WHO pp. 1050.

Salah-Salah H. 2009. Dynamics of the urbanisation in a space littoral protects (case of El Kala). MSc. Thesis. Annaba. University of Annaba pp. 204. 


\section{Wahida KHERIFI, Lynda HECINI, Fedia BEKIRI, Houria KHERICI-BOUSNOUBRA}

Zanieczyszczenia pochodzenia kałowego w wodach jeziora Mellah i jego zlewni, pólnocnowschodnia Algieria

\section{STRESZCZENIE}

Jezioro Mellah, położone blisko Morza Śródziemnego, w północnowschodniej Algierii, zalicza się do cennych siedlisk ornitologicznych ze względu na liczne, często migrujące, ptaki. Aby osiągnąć cel badań, pobierano próbki z siedemnastu punktów usytuowanych na terenach zurbanizowanych na obszarze zlewni. Próbki wody pobierano z różnych odcinków cieków (górne i dolne), jak też przy oczyszczalni ścieków i z jeziora Mellah w trakcie czterech sesji pomiarowych. $\mathrm{W}$ próbkach wody $\mathrm{z}$ różnych stanowisk w jeziorze i jego dopływach w laboratorium Katedry Zdrowia i Ludności, w El Taref analizowano parametry biologiczne (bakterie grupy coli i streptokoki) poprzez określenie najbardziej prawdopodobnej liczby (NPL) drobnoustrojów z wykorzystaniem tabel McGrady'ego. Przetwarzano uzyskane wyniki celem ustalenia źródła zanieczyszczeń kałowych w wodach i określenia przestrzennej i czasowej zmienności tego stosunku. Wykorzystano do tego stosunek Bourgeois. W ten sposób uzyskano informacje o zanieczyszczeniach pochodzących w porze suchej ze ścieków bytowych. Zimą zanieczyszczenia pochodziły głównie od zwierząt z parku w El Kala.

Słowa kluczowe: dopływy, jezioro Mellah, parametry biologiczne, stosunek Bourgeois, ścieki, zanieczyszczenia pochodzenia kałowego 